\title{
In vitro Propagation of Canna edulis Ker. by Longitudinal Shoot-split Method
}

\author{
Takashi HosokI and Hideo SASAKI \\ Laboratory of Vegetable and Ornamenal Horticulture, Faculty of \\ Agriculture, Shimane University, Nishikawatsu-cho 1060 \\ Matsue 690 Japan
}

(Received July 2, 1991)

(Accepted August 5, 1991)

\begin{abstract}
A procedure for in vitro propagation of Canna edulis Ker. (edible Canna, Queensland arrowroot) is described. Growth of shoot tips was optimum on Murashige and Skoog (MS) medium supplemented with $0.1 \mathrm{mg} / l \mathrm{~N}^{6}$ benzylaminopurine (BA). Continuous shoot multiplication was achieved by longitudinally splitting the shoot axis and subsequent division of elongated axillary shoots every 26 days. Rooting rate was $100 \%$ on either MS basal medium or $0.1 \mathrm{mg} / \mathrm{l} 3$-indolebutyric acid (IBA) supplemented MS medium. More than $90 \%$ of the rooted plantlets were successfully established in soil.
\end{abstract}

\section{Introduction}

Canna edulis Ker. (Queensland arrowroot) is an edible Canna, native to the Andes, South America that is being domesticated to South Asia or North India as a rhizomatous crop for starch production ${ }^{1)}$. The starch in the rhizome is processed for cookie production as well as cooked after boiling like cassava or taro. The production of this crop is done by rhizome division ${ }^{1)}$. However, this conventional method is slow and vulnerable to virus infection during multiplication. Therefore, a rapid propagation method through in vitro system is desired. In vitro propagation of ornamental canna ( $C$. indica) was reported to be possible by separation of axillary shoots ${ }^{2}$. However, the multiplication rate per a certain period was not mentioned. To date, there has been no report on in vitro propagation of Canna edulis.

The objective of this study is to establish a rapid in vitro propagation method using longitudinal shoot-split method, by which axillary buds are forced to grow. This method was successful in propagation of wasabi, Japanese horseradish ${ }^{3)}$ and herbaceous peony ${ }^{4)}$.

\section{Materials and Methods}

Scale leaves around the shoot tips were removed and trimmed to about $1 \mathrm{~cm}^{3}$ cubes. They were then cleaned with tap water and a bit of detergent. The cubes were soaked in a solution of sodium hypochlorite (active chlorine, $0.6 \%$ ) for $10 \mathrm{~min}$ and washed two times in sterile water. They were further trimmed to $2-3 \mathrm{~mm}^{3}$ cubes by removing immature scale leaves. The explants were put into test tubes ( $2 \mathrm{~cm}$ in diameter, $15 \mathrm{~cm}$ in height) containing $15 \mathrm{~m} l$ agar solid medium. The test tubes were covered with aluminum foil. The basal medium consisted of MS major salts and FeEDTA ${ }^{5}$, Ringe and Nitsch minor elements and vitamins ${ }^{6}, 2 \%$ sucrose and $0.8 \%$ agar at $\mathrm{pH} 5.6$. The cultures 
Table 1. Effect of BA on shoot length and leaf number of C. edulis (10 explants per treatment).

\begin{tabular}{ccc}
\hline $\begin{array}{c}\text { BA } \\
(\mathrm{mg} / \mathrm{l})\end{array}$ & $\begin{array}{c}\text { Shoot length } \\
(\mathrm{cm})\end{array}$ & Leaf numbers \\
\hline 0 & $0.6 \mathrm{a}$ & $0.4 \mathrm{a}$ \\
0.1 & $2.5 \mathrm{~b}$ & $1.2 \mathrm{~b}$ \\
1.0 & $1.4 \mathrm{a}$ & $0.8 \mathrm{a}$ \\
\hline
\end{tabular}

Values within columns followed by different letter are significantly different at $\mathrm{P}=0.05$ by Duncan's multiple range test.
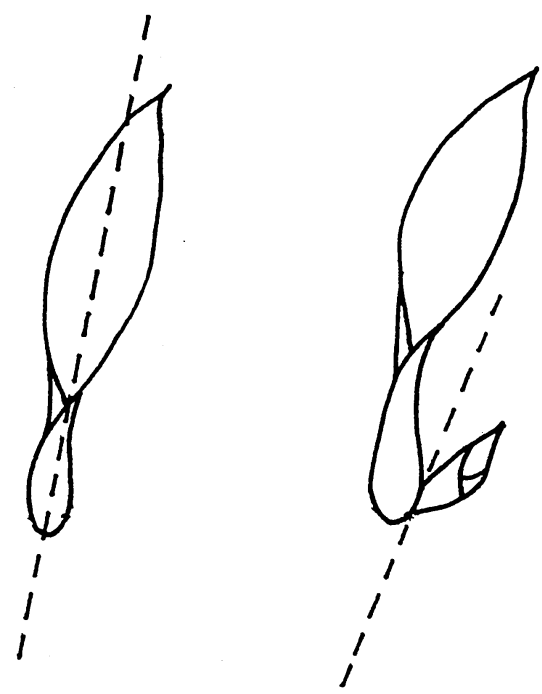

Fig. 1 Multiplication methods of $C$. edulis (dotted lines indicate split/division): longitudinal splitting of shoot axis (left), separation of axillary shoots that generated de novo (right).

were placed under $16 \mathrm{hr}$ illumination of $52 \mu \mathrm{mol} \cdot \mathrm{s}^{-1} \cdot \mathrm{m}^{-2}$ of cool-white fluorescent light at $28^{\circ} \mathrm{C}$.

\section{Results and Discussion}

Establishment of shoot tip culture. To promote growth of shoot tips, BA $(0,0.1 \mathrm{or} 1 \mathrm{mg} / l)$ was supplemented to the basal medium. Ten explants were used per treatment. One month after culture initiation, shoot length and leaf number were recorded. A supplement of $0.1 \mathrm{mg} / l \mathrm{BA}$ was optimal among the tested concentrations (Table 1). This concentration was also the best in ornamental canna ${ }^{2}$.

Shoot multiplication. Eleven shoot tips $\left(2-3 \mathrm{~mm}^{3}\right.$ cube) were cultured on $0.1 \mathrm{mg} / l \mathrm{BA}$ supplemented MS medium for 2 months. They grew to $7.5 \mathrm{~cm}$ in height and developed 3 leaves. Of the 11 shoots, only 2 gave rise to branching shoots. The other shoots just grew without giving rise them. Probably, axillary buds kept apical dominance. Therefore, we attempted to promote their growth by splitting shoot-axis longitudinally (Fig. 1). By this method, growth of axillary buds started on account of breakage of apical dominace. The elongated axillary shoots were then cut off and cultured individually on fresh media. This shoot-split method was repeatable at least 6 times at about 26 day 
intervals when the shoots reached about $7 \mathrm{~cm}$ in length (Table 2). Including separation of branching shoots which generated de novo (about 20\% of total explants), approximately 1.8 new shoots were obtained from each division; the multiplication rate did not reach the double because some of the shoots did not give rise to axillary shoots even after shoot-splitting. Compared to the shoot split method of Japanese horseradish ${ }^{3)}$ and herbaceous peony ${ }^{4)}$, the multiplication rate of $C$. edulis was about half. However, this method is still efficient for this plant since only $20 \%$ of the explants generate branching shoots if shoot-splitting is not conducted. Moreover, multiplication by separation of branching shoots has an advantage over adventitious bud formation through callus since the

Table 2. Multiplication by shoot-split and subsequent division of axillary shoots in C. edulis (11 to 45 explants per division).

\begin{tabular}{lccc}
\hline $\begin{array}{l}\text { The number of times } \\
\text { of shoot split/division } \\
\text { (day-interval to next } \\
\text { division) }\end{array}$ & $\begin{array}{l}\text { The number } \\
\text { of divided } \\
\text { shoots }\end{array}$ & $\begin{array}{l}\text { Shoot length } \\
\text { just before } \\
\text { division(cm) }\end{array}$ & $\begin{array}{l}\text { Leaf number } \\
\text { just before } \\
\text { division }\end{array}$ \\
\hline $1(30)$ & 1.8 & 7.5 & 3.0 \\
$2(28)$ & 1.8 & 6.6 & 2.5 \\
$3(24)$ & 1.8 & 6.7 & 2.1 \\
$4(26)$ & 1.8 & 7.3 & 2.7 \\
$5(27)$ & 1.8 & 6.9 & 2.5 \\
$6(25)$ & 1.7 & 7.2 & 2.3 \\
(NS) & NS & NS & NS \\
\hline
\end{tabular}

Ns Nonsignificant within columns by Duncan's multiple range test.

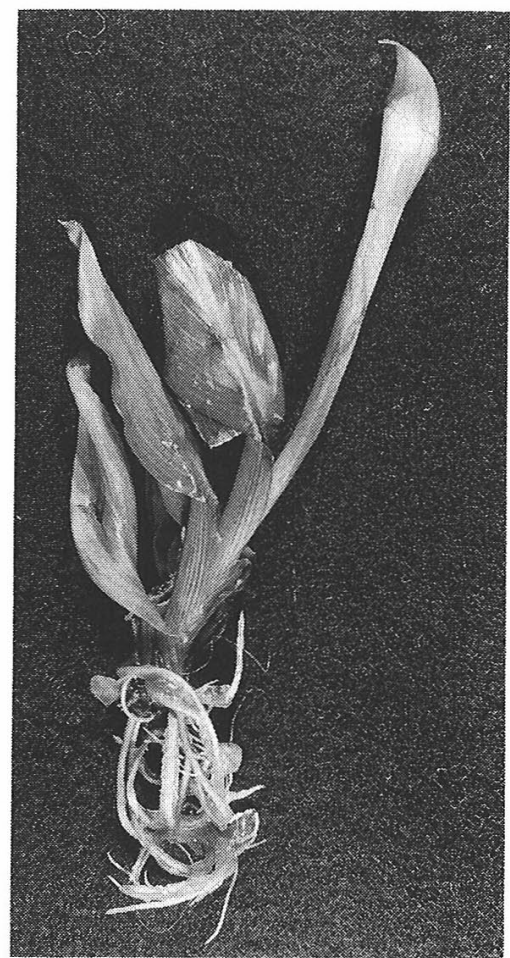

Fig. 2 A rooted plantlet of $C$. edulis in $0.1 \mathrm{mg} / l \mathrm{IBA}$ supplemented MS medium (about $7 \mathrm{~cm}$ in height, one month after culture). 
chance of somaclonal variation is low.

Rooting and acclimatization ex vitro. The rooting rate of the shoots was $100 \%$ either on the basal medium or $0.1 / l$ IBA supplemented medium 2 weeks after culture. The root number and root length (longest one) did not differ significantly by t-test between the above two media (2.0 and 2.0 in number, 7.6 and $5.8 \mathrm{~cm}$, respectively). Rooted plantlets (Fig. 2) were taken out from the test tubes and planted in trays containing porous sandy soil, covered with a plastic film and cultured at $25^{\circ} \mathrm{C}$ under continuous illumination of the same light intensity as in in vitro culture. The plantlets were watered daily and fertilized with $15 \mathrm{~N}-8 \mathrm{P}-17 \mathrm{~K}(2.5 \mathrm{~g} / l)$ every other day. Eighteen days later, the plastic film was uncovered. Ninety two percent of the plantlets were established and transferred to pots.

In conclusion, starting with a shoot tip culture on $0.1 \mathrm{mg} / l \mathrm{BA}$ supplemented MS medium for 2 months, splitting elongated-shoots longitudinally and separating axillary shoots by about 1 month intervals, $1.8^{10}$ shoots could be theoretically obtained per year. All the shoots rooted easily on MS basal medium and most of them were successfully acclimatized to the ex vitro condition. This in vitro multiplication method is more rapid than the conventional method of rhizome division of Canna edulis.

\section{References}

1) Koyama, T., 1984. Plant resource-guide to research methods, p. 152-155, Koudansha Press, Tokyo.

2) Kromer, K., K. Kukulczanka, 1985. Acta Horticulturae, 167: 279-285.

3) Hosoki, T., K. Tsunoda, M. Hamada, M. Seo, 1986. Agriculture and Horticulture, 61: 995-996.

4) Hosoki, T., M. Ando, T. Kubara, M. Hamada M. Itami, 1989. Plant Cell Reports, 8: 243-246.

5) Murashige, T., F. Skoog, 1962. Physiol. Plant., 15: 473-497.

6) Ringe, F., J. P. Nitsch, 1968. Plant Cell Physiol., 9: 639-652.

\section{《和文要約》}

食用カンナの茎緃断法による in vitro 増殖

細木高志，佐々木秀夫

島根大学農学部

食用カンナ (Canna edulis Ker.) の in vitro 増殖法について検討した. 茎頂の生長は, $0.1 \mathrm{mg} / l$ の BA を添加した MS 培地で優れていた，茎葉の連続増殖は，茎を縦に分割し伸長してきた腋芽を 26 日おきに切 り離すことで可能であった。 発根は，MS 基本培地または $0.1 \mathrm{mg} / l$ の IBA 添加 MS 培地で $100 \%$ 認めら れた。発根した幼植物は $90 \%$ 以上が, 土壌に移した時活着した。 